\title{
Article
}

Arq Neuropsiquiatr 2010;68(2):246-251

\section{Executive dysfunction and motor symptoms in Parkinson's disease}

\author{
Indira Silveira Campos-Sousa', Raimundo Nonato Campos-Sousa', \\ Luiz Ataíde Jr. ${ }^{2}$, Marta Maria de Brito Soares', Kelson James Almeida'
}

\begin{abstract}
The aim of this study is to analyze executive function and motor symptoms in patients with idiopathic Parkinson's disease (PD). The sample consisted of 44 subjects with PD between the ages of 45 to 75 , who were examined consecutively. The subjects were divided into two groups according to the duration of the disease. The control group was composed of spouses, family and accompanying members. Patients included were submitted to motor dysfunction evaluation using the UPDRS. The executive functions modalities analyzed included: operational memory, inhibitory control, planning, cognitive flexibility and inductive reasoning. Significant differences between the experimental and control groups were found in all the executive domains studied. Evidence of tremor, rigidity and bradykinesia correlation with executive dysfunction were not observed. Patients with PD, even in the initial phase of the disease, presented executive dysfunction. The cardinal motor signs of the disease were not correlated with the cognitive dysfunction found.

Key words: neuropsychology, neuropsychological tests, executive functions, idiopathic Parkinson's disease.
\end{abstract}

\section{Disfunções executivas e sintomas motores na doença de Parkinson}

\section{RESUMO}

O objetivo do estudo é avaliar as funções executivas e sintomas motores em pacientes portadores de doença de Parkinson. A amostra se constituiu de 44 portadores de doença de Parkinson com idade entre 45 e 75 anos, examinados consecutivamente, os quais foram divididos em dois grupos de acordo com o tempo de duração da doença. O grupo controle foi composto de acompanhantes ou cônjuges. Os sujeitos selecionados foram submetidos à avaliação motora utilizando-se a escala UPDRS e à avaliação das funções executivas nas modalidades: raciocínio indutivo, memória operacional, controle inibitório, planejamento e flexibilidade cognitiva. Os resultados apontaram diferenças significantes entre os grupos experimentais e controle nas modalidades analisadas. Não encontramos evidência de associação entre tremor, rigidez e bradicinesia com as funções executivas. Conclui-se que os pacientes com doença de Parkinson, mesmo nas fases iniciais da doença, apresentam comprometimento cognitivo executivo. Os sintomas motores da doença não estavam correlacionados às disfunções executivas.

Palavras-chave: neuropsicologia, testes neuropsicológicos, funções executivas, doença de Parkinson.

Parkinson's disease (PD) is a progressive neurodegenerative condition characterized by tremor, rigidity, bradykinesia and postural instability. Non-motor symptoms such as autonomic and cognitive dysfunction are present but little is known ${ }^{1}$. However, it was reported that the preva- lence of cognitive impairment or executive dysfunction in PD can reach $93 \%$ if adequate neuropsychological instruments are performed ${ }^{2}$. Cognitive and mental symptoms could be as incapacitating as motor symptoms which cause problems for both patients and caregivers ${ }^{3}$. Nigroestriatal 
circuit degeneration results in low concentration of striatal dopamine producing motor symptoms characteristic of the disease while low dopaminergic input from ventral tegmental mesencephalic area to the frontal and limbic regions is the neurochemical process which expresses cognitive-behavioral dysfunction in $\mathrm{PD}^{4}$. Other studies have found the reduction of the activity of frontostriatal loops in addition to reduction of dopaminergic input from ventral tegmental area to the frontal lobes ${ }^{5,6}$. Braak et al. suggested that these changes in PD are secondary to an ascendant progression process. Initially, there are lesions on the brainstem and anterior olphatory nucleus. Subsequently, it is manifested by substantia nigra neuronal lesions and finally cortical area involvement, from anteromedial temporal mesocortex to neocortex where it reaches associative cortex and prefrontal areas?

The neuropsychological function consists of a complex group which includes attention, memory, language, reasoning and executive functions. Executive function $(\mathrm{EF})$ is a set of cognitive abilities which permit the start of activities, planning, programming and sequencing of actions, self regulation and task monitoring, correct selections of behavior and conduct, mental work flexibility and time and space organization ${ }^{8}$. Dysfunction in this area which is coordinated by prefrontal region is called executive dysfunction (ED). It is characterized by difficulties to start actions, decrease in motivation and drive, planning difficulties based on priorities and the maintenance of activity sequence necessary to reach an object ${ }^{8}$. To understand the working of this group of functions is of paramount importance for the development of evaluation and rehabilitation strategies, improving the prognosis and life quality of the patients.

The aim of the study is to better understand this cognitive dysfunction so prevalent in PD through analytic study of patients chosen by diagnostic criteria and by using specific neuropsychological instruments to evaluate the executive domain.

\section{METHOD}

The sample consisted of members of the community and PD patients consecutively examined in the Movement Disorders outpatient clinic of Getúlio Vargas Hospital and the Federal University of Piauí. The patients were evaluated and put into two groups (PD1 and PD2). The PD1 group consisted of 23 patients with up to 3 years of the disease duration and the PD2 group 21 patients with more than 3 years of the onset. A brain magnetic resonance imaging (MRI) was performed in all PD patients to exclude other kinds of parkinsonism. The control group (CG) was composed of 25 normal subjects selected from spouses, family or accompanying members with the same social demographic characteristics as the experimental groups.
The PD groups were composed of subjects between the ages of 45 to 75, who fulfilled the diagnostic criteria cited by LANG to separate PD from other kinds of parkinsonism ${ }^{8}$. Individuals with depression, neurological or psychiatric disorders such as delirium or hallucinations, dementia and who had undergone neurosurgery were excluded. All of the subjects of the study underwent screening to investigate depressive symptomatology through BECK Depression Inventory ${ }^{10}$. The Mini Mental Status Examination (MMSE) $)^{11}$, basic daily activity questionnaire ${ }^{12}$ and a structured neuropsychological interview ${ }^{13}$ were applied to assess subjects with severe cognitive impairment or dementia and exclude them from the study.

The PD groups underwent a neurological evaluation to determine the motor scores in section III of the Unified Parkinson's Disease Rating Scale (UPDRS). All of the subjects of the PD groups were examined in the "on" medication state with levodopa and/or dopaminergic drug. No patient was on anticholinergic drugs. Neuropsychological tests were applied in one session which lasted around one hour and forty minutes depending on the difficulty level of the subjects. The EF modalities analyzed included: operational memory, inhibitory control, planning, cognitive flexibility and inductive reasoning. To evaluate operational memory an inverse order digit subtest and letter-number sequencing (SLN) of Wechsler Adult Intelligence Scale (WAIS) were used. In the inhibitory control evaluation of part "B" of the Trail making test B (TMT B) and Stroop color and words test (SCWT) cards 2 and 3 , were used ${ }^{10}$.

In the planning mode the WAIS-III cube subtest and Rey complex figure (CFT) was used. To evaluate the cognitive flexibility the Wisconsin card sorting test (WCST) was given. Intuitive reasoning was explored by the Raven progressive matrix test ${ }^{10}$.

The statistic analysis was performed with the objective of evaluating the prevalence of the ED of the PD patients and in CG, as well as to analyze the existence of motor factors associated with ED. For the descriptive analysis, tables (standard deviation and media) were used with all variables studies. The analysis of the differences between the media of continuous dada was done through parametric tests (variance analysis - ANOVA). To verify where the differences occurred the Tukey test was carried out. To study EF and motor association the Pearson correlation test was used. The probability $\mathrm{p}<0.05$ to indicate statistic significance was established. The subjects in the study signed a term of free consent and knowledge. The current protocol was submitted to a research ethic committee from the Federal University of Pernambuco, Brazil.

\section{RESULTS}

Inclusion tests were given to 52 subjects with PD of whom 44 fulfilled the inclusion criteria for the study, 3 
Table 1. Comparison of the demographic variables and the duration of PD in the groups.

\begin{tabular}{|c|c|c|c|c|c|c|c|}
\hline \multirow{2}{*}{ Variable } & & & \multicolumn{5}{|c|}{ Parameters } \\
\hline & & & $\mathrm{N}$ & Media & Minimum & Maximum & Deviation \\
\hline Age (general) & & $\begin{array}{l}\text { CG } \\
\text { PD1 } \\
\text { PD2 }\end{array}$ & $\begin{array}{l}25 \\
23 \\
21\end{array}$ & $\begin{array}{l}59.08 \\
63.22 \\
59.67\end{array}$ & $\begin{array}{l}45 \\
53 \\
45\end{array}$ & $\begin{array}{l}75 \\
75 \\
73\end{array}$ & $\begin{array}{l}8.89 \\
7.44 \\
9.67\end{array}$ \\
\hline Schooling (time-year) & & $\begin{array}{l}\text { CG } \\
\text { PD1 } \\
\text { PD2 }\end{array}$ & $\begin{array}{l}25 \\
23 \\
21\end{array}$ & $\begin{array}{l}8.12 \\
5.70 \\
6.24\end{array}$ & $\begin{array}{l}0 \\
0 \\
2\end{array}$ & $\begin{array}{l}12 \\
12 \\
12\end{array}$ & $\begin{array}{l}4.07 \\
3.62 \\
3.87\end{array}$ \\
\hline Gender (age) & Male & $\begin{array}{l}\text { CG } \\
\text { PD1 } \\
\text { PD2 }\end{array}$ & $\begin{array}{c}8 \\
11 \\
10\end{array}$ & $\begin{array}{l}58.13 \\
60.91 \\
55.40\end{array}$ & $\begin{array}{l}46 \\
53 \\
45\end{array}$ & $\begin{array}{l}75 \\
70 \\
73\end{array}$ & $\begin{array}{c}11.52 \\
7.04 \\
10.48\end{array}$ \\
\hline & Female & $\begin{array}{l}\text { CG } \\
\text { PD1 } \\
\text { PD2 }\end{array}$ & $\begin{array}{l}17 \\
12 \\
11\end{array}$ & $\begin{array}{l}59.53 \\
65.33 \\
63.55\end{array}$ & $\begin{array}{l}45 \\
54 \\
49\end{array}$ & $\begin{array}{l}74 \\
75 \\
73\end{array}$ & $\begin{array}{l}7.73 \\
7.45 \\
7.30\end{array}$ \\
\hline $\begin{array}{l}\text { Duration of disease } \\
\text { (time) }\end{array}$ & & $\begin{array}{l}\text { DP1 } \\
\text { DP2 }\end{array}$ & $\begin{array}{l}23 \\
21\end{array}$ & $\begin{array}{l}1.75 \\
6.52\end{array}$ & $\begin{array}{l}0 \\
4\end{array}$ & $\begin{array}{c}3 \\
19\end{array}$ & $\begin{array}{l}0.89 \\
3.37\end{array}$ \\
\hline
\end{tabular}

PD1: group with PD up to 3 years; PD2: group with PD for 3 years or more; CG: control group.

Table 2. Distribution of the media of the motor functions (Motor) and media of the scores separately which compose Sector III of the UPDRS among the patients.

\begin{tabular}{|c|c|c|c|c|c|c|c|}
\hline Symptom & Groups & $\mathrm{N}$ & Media* & Minimum value & Maximum value & Deviation & ANOVA \\
\hline Tremor & $\begin{array}{l}\text { PD1 } \\
\text { PD2 }\end{array}$ & $\begin{array}{l}23 \\
21\end{array}$ & $\begin{array}{l}5.13^{\mathrm{a}} \\
5.52^{\mathrm{a}}\end{array}$ & $\begin{array}{l}1.00 \\
0.00\end{array}$ & $\begin{array}{l}11.00 \\
12.00\end{array}$ & $\begin{array}{l}2.91 \\
3.87\end{array}$ & 0.71 \\
\hline Rigidity & $\begin{array}{l}\text { PD1 } \\
\text { PD2 }\end{array}$ & $\begin{array}{l}23 \\
21\end{array}$ & $\begin{array}{l}5.57^{a} \\
6.67^{a}\end{array}$ & $\begin{array}{l}1.00 \\
1.00\end{array}$ & $\begin{array}{l}13.00 \\
14.00\end{array}$ & $\begin{array}{l}3.03 \\
3.26\end{array}$ & 0.25 \\
\hline Bradykinesia & $\begin{array}{l}\text { PD1 } \\
\text { PD2 }\end{array}$ & $\begin{array}{l}23 \\
21\end{array}$ & $\begin{array}{l}12.74^{\mathrm{a}} \\
15.86^{\mathrm{a}}\end{array}$ & $\begin{array}{l}1.00 \\
2.00\end{array}$ & $\begin{array}{l}26.00 \\
26.00\end{array}$ & $\begin{array}{l}6.12 \\
6.09\end{array}$ & 0.09 \\
\hline Motor & $\begin{array}{l}\text { PD1 } \\
\text { PD2 }\end{array}$ & $\begin{array}{l}23 \\
21\end{array}$ & $\begin{array}{l}28.26^{a} \\
35.19^{a}\end{array}$ & $\begin{array}{c}12.00 \\
8.00\end{array}$ & $\begin{array}{l}56.00 \\
57.00\end{array}$ & $\begin{array}{l}12.41 \\
12.68\end{array}$ & 0.07 \\
\hline
\end{tabular}

*The mean followed by the same letter do not differ among themselves to the level of 5\% probability using the Tukey test. PD1: group with PD up to 3 years; PD2: group with PD for 3 years or more.

patients with MRI signs of multiple system atrophy and 5 patients with signs of ischemic stroke were excluded. About $15 \%$ of patients included in PD group had nonspecific white matter MRI signal hyperintensities. The control group consisted of 25 people. The demographic data is found in Table 1. The severity of the PD groups was measured according to motor function sector III of the UPDRS. The total score varied from 8 to 57 points. No significant difference in the motor scores was found among the PD groups. Likewise, the media of the motor scores studied for isolated symptoms such as tremor $(\mathrm{p}=0.71)$, rigidity $(\mathrm{p}=0.25)$ and bradykinesia $(\mathrm{p}=0.09)$ was not significant (Table 2).

The media and comparisons of the results of EF modalities and the tests used to evaluate each one among the groups studied are shown in Table 3. In operating mode memory, the control group presented greater scores than the PD groups which revealed significant differences between the CG and PD. No significant difference was noted between the PD groups. For inhibitory control the control group carried out the test TMT B in less time com- pared to the two PD groups and there were significant statistical differences. Even though the CG made fewer mistakes, there was no statistical difference with the PD groups. No significant differences were found among the PD1 and PD2 groups in TMT B test (time and errors). In SCWT2 test, the control group had the greater number of correct answers when compared to the PD groups showing significant statistical differences. In SCWT3 test significant differences were observed only among the media of the control group (35.83) and with media of the PD1 group (24.20). The CG had scores a slightly higher than the PD2 group but without significance.

In the planning evaluation with the Cube test, the control group was different from both PD groups. In the CFT test, the difference was significant only between the control group and PD2 group. None the tests used to evaluate planning showed a difference between PD1 and PD2 groups. In the investigation of cognitive flexibility, the WCST (completed category and preservative response) pointed out a difference in the CG and the PD groups. However, no significant difference was noted be- 
Table 3. Comparison among the results obtained from the tests of the different modalities for executive function among the groups studied.

\begin{tabular}{|c|c|c|c|c|c|c|c|}
\hline Test & Groups & $\mathrm{N}$ & Media* & Minimum value & Maximum value & Deviation & ANOVA p-valor \\
\hline OI DIGIT & $\begin{array}{l}\text { Control } \\
\text { PD1 } \\
\text { PD2 }\end{array}$ & $\begin{array}{l}25 \\
23 \\
21\end{array}$ & $\begin{array}{l}4.96^{a} \\
3.70^{b} \\
3.62^{b}\end{array}$ & $\begin{array}{l}2 \\
2 \\
2\end{array}$ & $\begin{array}{l}12 \\
7 \\
6\end{array}$ & $\begin{array}{l}2.07 \\
1.55 \\
1.47\end{array}$ & $<0.01$ \\
\hline SLN & $\begin{array}{l}\text { Control } \\
\text { PD1 } \\
\text { PD2 }\end{array}$ & $\begin{array}{l}25 \\
21 \\
21\end{array}$ & $\begin{array}{l}7.84^{a} \\
4.14^{b} \\
4.19^{b}\end{array}$ & $\begin{array}{l}2 \\
2 \\
2\end{array}$ & $\begin{array}{l}11 \\
10 \\
10\end{array}$ & $\begin{array}{l}2.54 \\
2.52 \\
2.27\end{array}$ & $<0.01$ \\
\hline TMT B-t & $\begin{array}{l}\text { Control } \\
\text { PD1 } \\
\text { PD2 }\end{array}$ & $\begin{array}{l}23 \\
19 \\
21\end{array}$ & $\begin{array}{l}152.17^{a} \\
264.47^{b} \\
278.14^{b}\end{array}$ & $\begin{array}{l}60 \\
60 \\
60\end{array}$ & $\begin{array}{l}360 \\
415 \\
420\end{array}$ & $\begin{array}{c}81.13 \\
115.98 \\
97.76\end{array}$ & $<0.01$ \\
\hline TMT B-e & $\begin{array}{l}\text { Control } \\
\text { PD1 } \\
\text { PD2 }\end{array}$ & $\begin{array}{l}24 \\
19 \\
20\end{array}$ & $\begin{array}{l}0.92^{\mathrm{a}} \\
1.37^{\mathrm{a}} \\
1.70^{\mathrm{a}}\end{array}$ & $\begin{array}{l}0 \\
0 \\
0\end{array}$ & $\begin{array}{l}4 \\
3 \\
4\end{array}$ & $\begin{array}{l}1.25 \\
1.16 \\
1.34\end{array}$ & $<0.12$ \\
\hline SCT2-ca & $\begin{array}{l}\text { Control } \\
\text { PD1 } \\
\text { PD2 }\end{array}$ & $\begin{array}{l}25 \\
21 \\
21\end{array}$ & $\begin{array}{l}63.88^{a} \\
42.24^{b} \\
45.81^{b}\end{array}$ & $\begin{array}{l}26 \\
18 \\
22\end{array}$ & $\begin{array}{c}100 \\
80 \\
71\end{array}$ & $\begin{array}{l}17.31 \\
16.92 \\
15.87\end{array}$ & $<0.01$ \\
\hline SCT3-ca & $\begin{array}{l}\text { Control } \\
\text { PD1 } \\
\text { PD2 }\end{array}$ & $\begin{array}{l}24 \\
20 \\
20\end{array}$ & $\begin{array}{l}35.83^{a} \\
24.20^{b} \\
27.95^{b}\end{array}$ & $\begin{array}{c}19 \\
9 \\
10\end{array}$ & $\begin{array}{l}60 \\
53 \\
47\end{array}$ & $\begin{array}{l}11.05 \\
12.03 \\
10.81\end{array}$ & $<0.01$ \\
\hline CUBE & $\begin{array}{l}\text { Control } \\
\text { PD1 } \\
\text { PD2 }\end{array}$ & $\begin{array}{l}25 \\
23 \\
21\end{array}$ & $\begin{array}{l}26.72^{a} \\
15.22^{b} \\
18.22^{b}\end{array}$ & $\begin{array}{l}5.00 \\
6.00 \\
6.00\end{array}$ & $\begin{array}{l}43.00 \\
46.00 \\
43.00\end{array}$ & $\begin{array}{c}11.05 \\
9.23 \\
10.00\end{array}$ & $<0.01$ \\
\hline CFT-C & $\begin{array}{l}\text { Control } \\
\text { PD1 } \\
\text { PD2 }\end{array}$ & $\begin{array}{l}25 \\
22 \\
20\end{array}$ & $\begin{array}{l}30.84^{a} \\
29.43^{a} \\
26.20^{b}\end{array}$ & $\begin{array}{c}16.50 \\
18.00 \\
8.00\end{array}$ & $\begin{array}{l}36.00 \\
36.00 \\
35.00\end{array}$ & $\begin{array}{l}5.59 \\
4.43 \\
8.10\end{array}$ & $<0.05$ \\
\hline WSCT-C & $\begin{array}{l}\text { Control } \\
\text { PD1 } \\
\text { PD2 }\end{array}$ & $\begin{array}{l}24 \\
21 \\
21\end{array}$ & $\begin{array}{l}5.17^{\mathrm{a}} \\
2.43^{\mathrm{b}} \\
2.52^{\mathrm{b}}\end{array}$ & $\begin{array}{l}1.00 \\
0.00 \\
0.00\end{array}$ & $\begin{array}{l}6.00 \\
6.00 \\
6.00\end{array}$ & $\begin{array}{l}1.43 \\
1.54 \\
1.54\end{array}$ & $<0.01$ \\
\hline WSCT-fms & $\begin{array}{l}\text { Control } \\
\text { PD1 } \\
\text { PD2 }\end{array}$ & $\begin{array}{l}24 \\
21 \\
21\end{array}$ & $\begin{array}{l}1.08^{\mathrm{a}} \\
0.95^{\mathrm{a}} \\
1.48^{\mathrm{a}}\end{array}$ & $\begin{array}{l}0.00 \\
0.00 \\
0.00\end{array}$ & $\begin{array}{l}4.00 \\
4.00 \\
8.00\end{array}$ & $\begin{array}{l}1.14 \\
1.28 \\
1.83\end{array}$ & 0.52 \\
\hline WSCT-pr & $\begin{array}{l}\text { Control } \\
\text { PD1 } \\
\text { PD2 }\end{array}$ & $\begin{array}{l}24 \\
21 \\
21\end{array}$ & $\begin{array}{l}27.50^{a} \\
46.57^{b} \\
44.14^{b}\end{array}$ & $\begin{array}{l}8.00 \\
6.00 \\
4.00\end{array}$ & $\begin{array}{l}61.00 \\
70.00 \\
98.00\end{array}$ & $\begin{array}{l}14.91 \\
16.87 \\
20.56\end{array}$ & $<0.01$ \\
\hline $\begin{array}{l}\text { RAVEN-p } \\
\text { (ponto) }\end{array}$ & $\begin{array}{l}\text { Control } \\
\text { PD1 } \\
\text { PD2 }\end{array}$ & $\begin{array}{l}22 \\
22 \\
21\end{array}$ & $\begin{array}{l}32.59^{a} \\
21.45^{b} \\
22.62^{b}\end{array}$ & $\begin{array}{l}10 \\
11 \\
13\end{array}$ & $\begin{array}{l}78 \\
62 \\
50\end{array}$ & $\begin{array}{l}10.91 \\
6.88 \\
7.66\end{array}$ & $<0.01$ \\
\hline
\end{tabular}

*The mean followed by the same letter "a"/"b" do not differ among themselves to the level of $5 \%$ probability using the Tukey test. Oi Digit: Inverse order; SLN: subtest of digit extension; TMT B-t; Part "B" of the Trail test. SCT; Stroop Test of color and words, cards 2 and 3. Tests parameters - t: time (in seconds); e: mistakes; ca: correct answers; CFT: Rey complex figure; WSCT: Wisconsin test; Tests parameters - c: completed category; fms: failure to maintain the set; pr: preservative response; RAVEN-p: Raven progressive matrix test points; PD1: group with PD up to 3 years; PD2: group with PD for 3 years or more.

tween the two groups of patients. In the WCST test (failure to maintain the set) similar results among the groups were verified. In analyzing the inductive reasoning skills there was significant difference between the media of the CG and the PD groups. However, when comparing the two PD groups no difference was observed.

When the correlation between motor symptoms of $\mathrm{PD}$ - rigidity, tremor and bradykinesia- and each EF test given were studied, weak or no association between the cognitive modalities and the results of the motor function in UPDRS - sector III were observed (Table 4).

\section{DISCUSSION}

For many years, PD was described as a movement disorder with a tendency to neglect the mental dysfunction associated with the disease ${ }^{1,3}$. Recently there has been a systematic concern with the cognitive and behavioral aspects of the neurodegenerative disease. In this way the neuropsychological evaluation of the EF has been the object of growing interest of researchers. However, there still remain many doubts about the functioning of EF in neurodegenerative diseases and PD in particular.

The individuals of this study are characterized by a 
variation in regards to the level of education among the groups. It is known that intellectual experience in work activities could decrease the difficulties in carrying out neuropsychological tests in the subjects with little schooling $^{14}$. In the experimental groups, the duration of PD was not associated with the severity of the parkinsonian motor symptoms. This effect might have occurred because of the selection of patients since those older than 75 and/ or with severe tremor, bradykinesia, rigidity, postural instability and depression were excluded. This could have caused limitation in this study.

Neuropsychological evaluation of the EF showed low scores for PD patients in both stages with no statistical difference in the experimental groups suggesting that from the beginning of the disease the individuals with $P D$ already show difficulty in EF. Few studies have addressed the question of cognitive reserve in patients with PD. Greater performance in cognitive tests in PD patients in the initial phase associated with a high level of cognitive reserve has been described such as in other neurodegenerative diseases ${ }^{15}$. These results are in agreement with the findings of Foltynie et al. ${ }^{16}$, which also noted alterations in the cognitive domain in patients initiating PD symptoms, or without dementia and with light motor manifestations. This is also in agreement with the study of Muslimovic et al. ${ }^{17}$, which showed cognitive deficit mainly in the memory domain areas and EF in the early phase of PD.

\section{Fluid intelligence}

In the investigation of inductive reasoning or fluid intelligence through the Raven test, significant deficit for the experimental groups was observed when compared to the CG, confirming works by Duncan et al. ${ }^{18}$, who found correlations between frontal dysfunctions and difficulty in fluid intelligence tasks. This also is in agreement with the findings of Prabhakaran et al. ${ }^{19}$, who mapped the cerebral areas activated while a person is resolving items of the Raven test using functional MRI. This showed which areas of the cerebral areas were activated while the subject solved problems using simple reasoning perceptual processes, analytic problems and problems of perceptual comparison (task control).

\section{Operational memory}

The tests used to evaluate operational memory (working memory), SLN and inverse order digits, in DP1 as well as DP2 groups presented greater difficulty than the control group. Dubois and Pillon ${ }^{20}$ reported that the patients with PD presented alterations in operational memory when performing task which require short-term memory; inhibition of an interference of a stimuli; digital sequencing or special organization. Our findings are also in agreement with these studies related by Starkstein and
Table 4. Association measures among the means of the Motor scores in section III of UPDRS or scores separate from section III and results of tests of executive functions modalities studied.

\begin{tabular}{lcccc}
\hline & Motor & Tremor & Rigidity & Bradykinesia \\
\hline RAVEN-t & 0.0017 & 0.1663 & -0.1358 & 0.0094 \\
RAVEN-p & 0.0000 & 0.0047 & 0.0608 & -0.0317 \\
OI DIGIT. & -0.1118 & -0.1167 & 0.0166 & -0.0964 \\
SLN & -0.0460 & 0.0283 & 0.0226 & -0.1391 \\
TMT B-t(m) & -0.0216 & -0.0670 & -0.0943 & 0.0667 \\
TMT B-e & 0.1617 & 0.0329 & 0.0902 & 0.2132 \\
SCT2-CA & -0.0801 & -0.1598 & 0.0102 & -0.1043 \\
SCT3-CA & 0.0182 & 0.0221 & 0.1411 & -0.0304 \\
CUBES & -0.0526 & 0.0116 & -0.0232 & -0.0864 \\
CFT-p & -0.0628 & 0.1770 & -0.1239 & -0.1163 \\
WSCT-c & 0.1691 & 0.1344 & 0.2666 & 0.0790 \\
WSCT-fms & 0.0096 & -0.0527 & 0.0414 & 0.0807 \\
WSCT-pr & 0.0628 & 0.1030 & 0.0250 & 0.0406 \\
\hline
\end{tabular}

Values of $r$ of Pearson Correlation with lower results than 0.30 showed weak or no association among the variables. RAVEN-p: Raven progressive matrix test points; Oi Digit: Inverse order; SLN: subtest of digit extension; TMT B-t: Part "B" of the Trail test; SCT: Stroop Test of color and words, cards 2 and 3. Tests parameters - t: time (in seconds); e: mistakes; ca: correct answers; CFT: Rey complex figure; WSCT: Wisconsin test; Tests parameters - c: completed category; fms: failure to maintain the set; pr: preservative response.

Merello $^{21}$, which showed operational memory deficit in PD in tests which require correct coordination of two tasks simultaneously. The recent work of Beato et al. ${ }^{22}$, identified that patients with PD presented inferior performance to the control group in working memory tasks and levodopa therapy presents a positive effect on spatial operational memory.

\section{Inhibitory control}

Attention encompasses orientation and mental concentration directed by a task and inhibition of competitors. Distraction, interference of tasks by stimuli coming from the ambient, increases attention difficulty for individuals with frontal lobe disorders. In this study, the evaluation of inhibitory control indicated low scores for PD patients in regards to normal standards. In the study of Osternack-Pinto ${ }^{23}$ similar findings were found. PD patients had low scores in attention control tasks which require good operational memory and inhibitory control to resist interference of stimuli competing for attention. In the same study, low scores were also found in SCWT and TMT B tests in PD patients.

\section{Planning}

In the investigation of planning the tests showed a difference in the PD groups and the CG confirming the data found in literature ${ }^{3}$. Planning requires that an individual have the capacity to evaluate alternatives, make choic- 
es and study ideas necessary for carrying out the plan. In the qualitative analysis of the performance of PD patients in the CFT test, the majority of the patients evaluated in the study had difficulty in visual and perceptual organization, difficulty in starting a sequence, difficulty in choosing, rejecting and adopting alternative thought and conduct courses. The complexity was so great for these patients that many quit the task.

\section{Cognitive flexibility}

The WCST, which originally was developed to evaluate the ability of abstraction reasoning and to change from one line of thought to another, is cited as sensitive for operational and cognitive flexibility. In the investigation of cognitive flexibility with the use of WCST (completed category and persevering response) a significant statistical difference between the CG and the PD groups was found. In studies carried out by Taylor, Saint-Cry and Lang cited by Piovezan ${ }^{24}$, the use of WCST showed significant differences among the number of categories: there were persevering responses and a large number of errors to reach the first category, which suggest less ability in PD patients to make a plan of action when given a task ${ }^{24}$. Similar findings were found in the article of Sobreira et al. ${ }^{25}$ which evaluated the EF in PD and found scores below the average in the following tests: WCST, inverse digit order thus proving an involvement in the EF of these patients.

The PD patients scored lower when compared to the CG in all tests which evaluated EF, in those tests which needed quickness and motor skills (Cube, CFT, SCWT, TMT B) in their fulfillment as well as those that did not need them (SLN, inverse order digits, WCST, Raven).

One of our objectives was to verify if cognitive dysfunction is associated with the motor symptoms of PD when studied separately. We did not find evidence of association between tremor, rigidity and bradykinesia in the scores of the tests which evaluated EF. Possibly, these isolated symptoms are not predictive factors for the prevalence of cognitive deficits. This is partially in agreement with the findings of Piovezan ${ }^{24}$, which did not find correlation between executive deficits and scores for the scales Hoehn-Yahr and UPDRS. Also in agreement with the literature, Graham and $\operatorname{Sagar}^{26}$ and Mohr et al. ${ }^{27}$, indicated that such defects are part of a greater cognitive decline or which alternatively have these restrictions in a subgroup of patients and/or did not occur in the initial phase of the disease in the group studied.

In conclusion, the patients with PD had deficits in all tests which evaluated the modalities of EF when compared to the control group. There was little difference in the tests which evaluated executive cognitive domain between the PD groups. The cardinal motor symptoms of the disease, when individually studied, were not correlat- ed to ED and probably do not have predictive value for the development of future cognitive incapability or dementia.

\section{REFERENCES}

1. Kummer A, Teixeira A. Neuropsychiatry of Parkinson's disease. Arq Neuropsiquiatr 2009;67:930-939.

2. Pillon B, Czernecki V, Dubois B. Dopamine and cognitive function. Curr Opin Neurol 2003;16(Suppl 2):S17-S22.

3. Emre M. What Causes mental dysfunction in Parkinson's disease? Mov Disord 2003;18(Suppl):S63-S71.

4. Caixeta, L. Demências. São Paulo: Lemos-Editorial, 2004:146-147.

5. Javoy-Agid F, Agid Y. Is the mesocorticaldopaminergic system involved in PD? Neurology 1980;30:1326.

6. Pillon B, Czernecki V, Dubois B. Dopamine and cognitive function. Curr Opin Neurol 2003;16(Suppl 2):S17-S22.

7. Braak H, Del Tredici K, Rüb U, de Vos RA, Jansen Steur EN, Braak E. Staging of brain pathology related to sporadic Parkinson's disease. Neurobiol Aging 2003;24:197-211.

8. Parenté R. Retraining cognition: techniques and applications. Maryland: Aspen Publishers, 1996.

9. Lang AE, Lozano AM. Parkinson's disease: first at two parts. N Eng J Med 1998;339:1044-1053.

10. Spreen O, Strauss E. A Compendium of neuropsychological tests: administration, norms, and commentary. 2nd Ed. New York: Oxford University Press, 1998.

11. Folstein MF, Folstein SE, Mchugh PR. Mini-mental state: a practical method for grading the cognitive state off patients for the clinician. J Psychiatr Res 1975;12:189-198.

12. Katz S, Downs TD, Cash HR, Grotz RC. Progress in the development of the index ADL. Gerontologist 1970;1:20-30.

13. American Psychological Association - APA. Presidential Task Force on the assessment of age-consistent memory decline cognitive and dementia: guidelines for the evaluation of dementia and age-related cognitive decline. Am Psychol 1998;53:1298-1303.

14. Osternack-Pinto K. [Análise Comparativa das funções neuropsicológicas de portadores de doença de Parkinson em estágios inicial e avançado: uma determinação de padrões para diagnóstico em população brasileira]. Thesis, University of São Paulo. São Paulo, 2006.

15. Sánchez JLMD, Rodriguez M, Carro J. Influence of cognitive reserve on neuropsychological functioning in Parkinson's disease. Acta Neuropsychiatrica 2002;14:207-215.

16. Foltynie T, Brayne CE, Robbins TW, Barker RA. The cognitive ability of an incident cohort of Parkinson's patients in the UK: the Campaign study. Brain 2004;127:550-560.

17. Muslimovic D, Post B, Speelman JD, Schmand B. Cognitive profile of patients with newly diagnosed Parkinson disease. Neurology 2005; 65:1239-1245.

18. Duncan J, Emslie H, Williams P, Johnson R, Freer C. Intelligence and the frontal lobe: the organization of goal-directed behavior. Cogn Psychol 1996;30:257-303.

19. Prabhakaran V, Smith JAL, Desmond JE, Glover GH, Gabrieli JDE. Neural substances of fluid reasoning: an fMRI study of neocortical activation during performance of the Raven's progressive matrices test. Cogn Psychol 1997; 33:43-63.

20. Dubois B, Pillon B. Cognitive deficits in Parkinson's disease. J Neurol 1997; 24:2-8.

21. Starkstein SE, Merello M. Psychiatry and cognitive disordens in Parkinson's disease. Cambridge University Press 2002:88-113.

22. Beato R, Levy R, Pillon B, et al. Working memory in Parkinson's disease patients: clinical features and response to levodopa. Arq Neuropsiquiatr 2008 66:147-51

23. Osternack-Pinto K. [Análise Comparativa das funções neuropsicológicas de portadores de doença de Parkinson em estágios inicial e avançado: uma determinação de padrões para diagnóstico em população brasileira]. Thesis, University of São Paulo. São Paulo, 2006.

24. Piovezan MR. [Avaliação cognitiva em pacientes portadores de doença de Parkinson idiopática]. Dissertation, Federal University of Paraná. Curitiba, 2006.

25. Sobreira EST, Pena MCS, Filho THS, et al. Executive functions in Parkinson's disease. Dement Neuropsychol 2008;2:206-209.

26. Graham JM, Sagar HJ. A data-driven approach to the study of heterogenity in idiophatic Parkinson's disease: identification of three distinct subtypes. Mov Disord 1999;14:10-20.

27. Mohr E, Juncos J, Cox C, Litvan I, Fedio P, Chase TN. Selective deficits in cognitions and memory in high-functioning Parkinsonian patients. J Neurol Neurosurg Psychiatry 1990;53:603-606. 